\title{
Rechtsprechung
}

\section{Die Bedeutung dauerhafter Restitutionsbemühungen deutscher Museen für Beutekunstklagen in den USA}

Surrogate's Court of the State of New York, County of Nassau, Urteil vom 30. März 2010 - 328146

\section{SURROGATE'S COURT OF THE STATE OF NEW YORK COUNTY OF NASSAU}

In the Matter of the Account of Proceedings of Hannah K. Flamenbaum, as Executor of the Estate of

RIVEN FLAMENBAUM,

File No. 328146

Deceased,

and the Application of Vorderasiatisches Museum for a Determination of the Validity and Enforceability of a Verified Claim.

- An ancient gold tablet, discovered during archaeological excavations in 1913 in the Ottoman Empire, disappeared from a Berlin museum in the immediate aftermath of World War II and reappeared almost sixty years later in the safe deposit box of a Holocaust survivor in Great Neck, New York. Before the Court today is a claim filed on behalf of the Vorderasiatisches Museum of the Federal Republic of Germany against the estate of Riven Flamenbaum for the return of that gold tablet. For the reasons set forth below, the claim is denied.

\section{Historical Background}

During excavations around the city of Ashur, now Qual'at Serouat, Iraq, during the early years of the twentieth century, a German team of archaeologists led by Dr. Walter Andrae discovered a small inscribed gold tablet. This tablet, sometimes referred to as a coin or amulet but in actuality the equivalent of a modernday construction document, was found in the foundation of the Ishta Temple and dates to the reign of the Assyrian King TukultiNinurta I (1243-1207 BCE). With the conclusion of the excavations in 1914, the gold tablet and other artifacts were transported to Basra and loaded on a freighter bound for Germany. The outbreak of World War I forced the freighter to change course for Lisbon, Portugal, where the items were stored until 1926. The artifacts were then released and shipped to a national museum in Berlin. The gold tablet was inventoried, assigned the number VA Ass 994 and was placed on display by the museum, beginning in 1934. Five years later, in the looming shadow of World War II, the museum was closed, and the gold tablet, along with other antiquities and works of art, was placed in storage. At the end of the war, it was discovered that the tablet was no longer in the museum, as reflected in a 1945 inventory. Today, the gold tablet is among the assets of Riven Flamenbaum's estate.

\section{Procedural History}

On March 10, 2006, Hannah K. Flamenbaum filed her account as executor of the estate of her father, Riven Flamenbaum. Mr. Flamenbaum died on April 3, 2003, a resident of Great Neck, leaving three children surviving, viz., Hannah (petitioner herein), Israel and Helen, all of whom are named in decedent's will, dated April 27, 1971, as equal residuary beneficiaries. The accounting petition names no other interested parties. The record reflects that Israel was properly served with an accounting citation while Helen filed a knowledgeable waiver and consent.

Israel (objectant herein) filed multiple objections to the account on May 25, 2006, one of which is that the executor failed, in schedule A of her account, to properly account for decedent's coin collection. Objectant states that the decedent possessed, among other gold coins, „one item identified as a 'gold wafer' which is believed to be an ancient Assyrian amulet and the property of a museum in Germany which has notified objectant's attorney of its claim." A copy of an email dated May 19, 2006 is attached to the objections. It reflects that Israel's attorney had notified the Vorderasiatisches Museum in Berlin about the executor's possession of the "gold tablet." A notice of appearance on behalf of the museum (claimant herein) and a notice of claim for the gold tablet were filed with the Surrogate's Court on October 5, 2006. Pursuant to a subsequent court conference in connection with the executor's accounting and the claim filed on behalf of the museum, it was decided that the court would determine the validity and enforceability of the claim as a preliminary step in the accounting proceeding.

Claimant filed a note of issue on January 22, 2008, but in a decision issued by this court on May 27, 2008 (Dec. No. 66), the court granted the estate's motion to vacate claimant's note of issue on the grounds that there were special circumstances warranting additional discovery. In a second decision, issued on September 18, 2008 (Dec. No. 615), the court declined to sign an order to show cause brought by objectant concerning the valuation of decedent's coins and other property, stating that the ownership of the gold tablet would first be tried as a discrete 
issue, prior to the trial on the issue of valuation and the other objections to the executor's account. A second note of issue was filed on January 7, 2009.

A hearing was held before this court on September 17, 2009. The director of the museum, Dr. Beate Salje, was the sole witness to testify at the hearing. The following exhibits, numbered (1) through (7), were admitted into the record: (1) the gold tablet; (2) a copy of the registration book showing the 1926 entry of VA Ass 994; (3) a picture of VA Ass 994; (4) excerpts from Dr. Walter Andrae's diary from the 1903-1914 excavations; (5) a report from Dr. Eckart Frahm, a professor of Assyriology at Yale University, dated August 17, 2006, confirming the authenticity of the gold tablet discovered in the decedent's estate; (6) Dr. Eckart Frahm's curriculum vitae; and (7) a color photo of the gold tablet. Following the proceeding, post-trial briefs and replies were submitted.

\section{Analysis}

Claimant seeks recovery of the gold tablet currently in the possession of the estate of Riven Flamenbaum. In response, the estate has raised the following defenses, which the court will address seriatim:

(A) the proceeding is barred by claimant's failure to file objections to the executor's account;

(B) claimant's rights were lost under the doctrine of spoils of war;

(C) claimant failed to meet its burden of proving legal ownership or a superior right of possession;

(D) the claim is barred by the statute of limitations; and

(E) the claim is barred by the doctrine of laches.

\section{(A) Failure to file objections}

The first argument put forth by the executor is that the museum's failure to file and serve objections to the account is fatal to the claimant's proceeding. The executor's final account was filed on March 10, 2006, at which time, as reflected in schedule $D$, there were no outstanding claims filed against the estate. Accordingly, the museum was not named as a party to the accounting proceeding nor did it receive service of a citation.

After the museum was advised of the estate's possession of the gold tablet, counsel for the museum appeared on the citation return date and subsequently filed a notice of appearance and notice of claim. As conceded in the estate's post-trial memorandum, claimant properly followed the procedure set forth in SCPA 1803, and its claim was then deemed rejected, pursuant to SCPA 1806 (3), by the fiduciary's failure to accept or reject the claim within 90 days from the date of its presentation.
SCPA 1808 provides that "whenever a fiduciary rejects a claim... all issues related to the validity and enforceability of the claim shall be tried and determined upon the judicial settlement of his account." Once a claim is filed and rejected, it is at issue to be decided by the Surrogate in the accounting proceeding, unless the claimant timely commences an action in another court (Matter of Schorer, 272 NY 247, 251 [1936]). While the statute provides that a claimant may file objections, it is the presentation of the claim under SCPA 1803 that serves as claimant's institution of a proceeding for the determination of the claim. Accordingly, claimant's rights in this proceeding are not affected by its failure to file objections.

\section{(B) The spoils of war doctrine}

The executor argues that the spoils of war doctrine applies, based upon the possibility that the former Union of Soviet Socialist Republics acquired the gold tablet along with other museum artifacts following the end of World War II. In support of this position, the executor cites the testimony of the museum director at the hearing. Dr. Salje testified that Russian troops took valuables out of the museum at the conclusion of World War II, and returned some, but not all, of the objects in 1957 (Transcript at 73). She further testified that the museum has no record or list of the objects taken by the Russian troops, which may have included the gold tablet (Transcript at 73-74). The estate claims that under the applicable laws of the Soviet Union and its successors in interest, cultural property taken by Russian troops during the occupation of Berlin after World War II was lawfully transferred from one sovereign to another and that this taking of the gold tablet by Russian troops extinguished the rights of the museum pursuant to international law. Thus, a party subsequently acquiring the tablet could obtain good title and transfer good title to others.

The museum maintains, however, that the spoils of war doctrine does not affect its right to the tablet because international authorities as well as the Hague Convention of 1907 forbid pillaging and plundering. Among other cases, the museum cites Menzel v List (49 Misc 2d 300 [Sup Ct, New York County 1966], mod 28 AD2d 516 [1 ${ }^{\text {st }}$ Dept 1967], partially revd on the issue of damages only, 24NY2d 91 [1969]), a replevin action for recovery of a painting confiscated by the Nazis. In Menzel, the court distinguished illegal plunder and pillage from lawful booty, the latter referring to conquered objects taken for military operations (id. at 305).

In reviewing the executor's assertion that the tablet was taken by Russian troops, the court notes that support for the estate's theory is largely circumstantial; the estate has not introduced evidence to raise this theory above the level of conjecture. However, as discussed more fully below, the estate's inability to present relevant proof in response to a claim filed more than 60 years after an event may be considered in the context of laches. 
The court finds that the estate has not adequately established facts upon which the court might consider the applicability of the spoils of war doctrine. Consequently, the court need not address the complex international law issues and conventions raised by learned counsel in this matter.

\section{(C) Burden of proof and title}

In order to prevail in an action for replevin, a claimant bears the burden of proof to show legal title or a superior right of possession (Batsidis v Batsidis, 9 AD3d 342 [2d Dept 2004]; Matter of Barett, 82NYS2d 137 [Sur Ct, Westchester County 1948]). The executor argues that despite the museum's control of the tablet in the years prior to 1945 , title to the tablet during that period of time may actually have rested with Turkey, which had dominion over the geographical area of the excavations. After World War II, the estate maintains that title may have been held by the Union of Soviet Socialist Republics, pursuant to the spoils of war doctrine, discussed above. On this basis, the estate asserts that the museum never had legal title to the tablet and therefore cannot have an immediate superior right of possession, which is required to successfully bring an action in replevin.

The museum disputes this argument. Claimant established by testimony and documentary evidence that an agent for the museum discovered the gold tablet during an authorized excavation of the city of Ashur in 1913, after which the tablet was transferred to the museum and remained there for 19 years until its disappearance at the end of World War II. The museum maintains that in connection with its replevin action it need not prove title superior to anyone other than the estate.

The court agrees with claimant that it need only prove that the museum's right to the tablet is superior to that of the estate (77 CJS, Replevin § 38). [P]laintiff need not establish good title against the whole world, but need only show good title as against the defendant" (id. at § 23). The estate's claim that a third party might have a claim to title is not a valid defense to the claim (id. at $\S 40$ ). The court finds that claimant met its initial burden of proof based upon the testimony and evidence introduced at the hearing.

\section{(D) Statute of limitations}

The parties agree that pursuant to CPLR 214 (3), the applicable statute of limitations in a replevin action is three years; the parties disagree on whether the statute began to run in 1945, at the time the tablet initially disappeared, or 61 years later, when claimant's demand for the tablet was made and refused. Under New York Law, a cause of action to recover a chattel against a party who has lawfully obtained the property arises not when the property is initially taken but, rather, when there is a demand for the return of the property and the demand is refused (the demand rule) (see Solomon R. Guggenheim Found v Lubell, 77 NY2d 311 [1991]; see also Menzel v List (49 Misc 2d 300, 304 [Sup Ct, New York County 1966], mod 28 AD2d $516\left[1^{\text {st }} d e p t\right.$
1967], partially revd on the issue of damages only, 24 NY2d 91 [1969]); and Kunstsammlung zu Weimar v Elicofon, 678 F2d 1150 [2d Cir 1982]). The museum filed its claim within three years after the estate rejected its demand. Accordingly, this proceeding is not barred by the statute of limitations. This approach does not mean, however, that in New York, where application of the demand rule is generally protective of owners (77 Am Jur POF $3 d$ 259, Proof of a Claim Involving Stolen Art or Antiquities § 32), an original owner may be lax in searching for missing or stolen property or may delay unreasonably in making a demand. The owner must be diligent, because even where the statute of limitations has not run, the claim may be barred by the doctrine of laches (Solomon R. Guggenheim Foundation v Lubell, 77 NY2d 311,321 [1991]).

\section{(E) The doctrine of laches}

The doctrine of laches is an equitable defense based on an unreasonable delay by a victim in bringing a claim, which in turn causes prejudice to the possessor (Czartoryski-Borbon v Turcotte, NYLJ, Apr. 28, 1999, at 27, col 2 [1 ${ }^{\text {st }}$ Dept]). The executor asserts that laches bars the museum's claim. In support of the application of this equitable remedy, the executor cites the conduct of the museum, which took no steps to report the tablet missing or to investigate or attempt to recover the tablet from the time it was discovered absent from the museum in 1945 until the present action was commenced in 2006. The tablet was never reported to any legal authority in any country as stolen; it was never listed as missing on any international art registry. Even after the museum learned in 1954 that the tablet was seen in the hands of a New York dealer, the museum made no attempt to contact the dealer, the New York City Police Department or Interpol or to otherwise seek recovery of the tablet. Instead, the museum allowed an additional 51 years to pass before reporting the tablet missing or making inquiry as to its whereabouts.

In Solomon R. Guggenheim Found v Lubell (77 NY2d 311 [1991]), the Court of Appeals considered whether a failure by the Guggenheim Museum to take reasonable action to locate a missing work of art over the course of twenty years was relevant to defendant's (a) statute of limitations defense and (b) defense based upon laches. The court specifically noted that the Guggenheim Museum failed to "inform other museums, galleries or artistic organizations of the theft, and additionally, did not notify the New York City police, the FBI, Interpol or any other law enforcement agencies" (id. at 315-316). While the court refused to impose a duty of diligence on the museum in the context of the statute of limitations defense, it noted that the lack of reasonable diligence would be considered by the trial judge in connection with laches (id. at 321).

In defense of the museum's failure to act, claimant cites Sotheby's, Inc. v Shene (2009 WL 762697, 2009 US Dist LEXIS 23596 [SD NY 2009]), which found no grounds for laches despite the fact that claimant waited 60 years to begin pursuing its claim (id. at 4). However, in that case, the court found that claimant's 
lack of action stemmed from its reasonable but erroneous belief that the object had been destroyed, noting that claimant only learned, 60 years later, that the object still existed, at which time it promptly took action to recover it (id.).

The museum argues that in the period immediately following World War II, its delay in searching for the gold tablet or reporting it stolen was entirely reasonable in the context of the political and financial restraints imposed by the museum's geographical location in East Berlin, which shortly thereafter became a part of the German Democratic Republic, a Soviet satellite state. However, claimant's post-trial brief cites Kunstsammlung zu Weimar v Elicofon (678 F2d 1150 [2d Cir 1982]), which also involved a claimant museum located in the German Democratic Republic in 1945. The contrast between the conduct of the plaintiff museum in Elicofon, in which the court returned the paintings, with that of the claimant in the case at bar, is striking. As described by the court in Elicofon, the director of that museum

"discovered the theft [in 1945], immediately reported the theft and thereafter engaged in diligent efforts to locate the paintings. These efforts included contacting various German museums and administrative organs, the Allied Control Council, the Soviet Military Administration, the United States State Department, and the Fogg and Germanic museums at Harvard (which were active in locating stolen art), all to no avail"

(id. at 1156). In Elicofon, the museum's immediate, diligent and ongoing search for the missing artwork precluded its opponent from successfully asserting a laches defense. Moreover, the political justification offered by claimant for its failure to act after World War II has no application once Berlin was reunified. In the years subsequent to Germany's reunification in 1989, the record reflects that the museum still made no effort to report the tablet missing or stolen.

The application of laches must be based upon the particular facts and circumstances of each case. The estate established by the museum's own admission that the disappearance of the tablet was only noted in the museum's internal records; it was not reported to authorities or listed on any registries. Further, although counsel for the museum repeatedly asserts that claimant had "no inkling of the whereabouts of the Object until... 2006" (Post-trial brief dated Nov. 23, 2009, p. 11), the evidence shows that the museum took no action after being given information about the tablet's whereabouts in 1954. It is not the length of the delay that is dispositive; rather, the issue is whether the delay was reasonable under the circumstances (Solomon $R$. Guggenheim Found. v Lubell, 77NY2d 311 [1991]). The court finds that the museum's lack of due diligence was unreasonable.

The estate must then meet the second prong of the test for laches by demonstrating prejudice to the possessor (Wertheimer $v$ Cirker's Hayes Storage Warehouse, Inc., 300 AD2d 117 [1 $1^{\text {st }}$ Dept 2002]). A defense of laches "is deficient if it fails to include al- legations showing not only a delay, but also injury, change of position, intervention of equities, loss of evidence, or other disadvantage resulting from such delay" (Glenesk v Guidance Realty Corp., 36 AD2d 852, 853 [2d Dept 1971] [internal citation omitted]. In Wertheimer, the court applied the doctrine of laches because although the original owner had knowledge of the location and possessor of the property, he failed to take any action to recover the painting for almost fifty years. The court held that this lack of due diligence prejudiced the defendant art gallery by making it impossible to prove that any of the gallery's predecessors in interest held good title to the painting (Wertheimer $v$ Cirker's Hayes Storage Warehouse, Inc., 300 AD2d 117, 118 [1 $1^{\text {st }}$ Dept 2002]); see also The Greek Orthodox Patriarchate of Jerusalem v Christies, Inc., 1999 WL 673347, 1999 US Dist LEXIS 13257 [SD NY 1999], in which the court noted in dicta that under New York law, a delay of almost seventy years in bringing the case prejudiced the family that possessed the manuscript by making it almost impossible to prove ownership). The court in Wertheimer further noted that laches applied even in the face of an allegation that the gallery had failed to inquire about the painting's background before purchasing it (Wertheimer $v$ Cirker's Hayes Storage Warehouse, Inc., 300 AD2d 117, 118 [1 ${ }^{\text {st }}$ Dept 2002]).

In the case at bar, the museum did not act even after it was provided with reasonably reliable information concerning the tablet's whereabouts in 1954. As a result of the museum's inexplicable failure to report the tablet as stolen, or take any other steps toward recovery, diligent good-faith purchasers over the course of more than sixty years were not given notice of a blemish in the title. That, coupled with the fact that Riven Flamenbaum's death has forever foreclosed his ability to testify as to when and where he obtained the tablet, has severely prejudiced the estate's ability to defend the museum's related claim to the tablet. These are precisely the circumstances in which the doctrine of laches must be applied.

\section{Conclusion}

The court finds that the museum's claim is barred by the doctrine of laches.

Counsel for the executor and counsel for objectant are directed to appear for a conference on the accounting proceeding on April 7, 2010, at 2:45 p.m.

This is the decision and order of this court.

Dated: March 30, 2010

JOHN B. RIORDAN

Judge of the Surrogate's Court 